\title{
KEPERCAYAAN ANIMISME DAN DINAMISME DALAM MASYARAKAT ISLAM ACEH
}

\author{
Ridwan Hasan \\ Jurusan Dakwah STAIN Malikussaleh \\ Jln. Cempaka No. 1 Lancang Garam, Lhokseumawe, 24300 \\ e-mail: ridwanmth@yahoo.com
}

\begin{abstract}
Abstrak: Masyarakat Aceh dikenal sebagai masyarakat yang religius. Agama Islam memainkan peranan penting dalam mengarahkan perilaku keseharian masyarakatnya. Namun, dalam kenyataan, masih terdapat beberapa unsur kepercayaan pra Islam yang berkembang dalam masyarakat. Penelitian ini berusaha menggali unsur kepercayaan animisme dan dinamisme dalam masyarakat Islam Aceh, mulai dari kelahiran sampai kematian maupun kepercayaan yang masih dipertahankan. Penelitian eksploratif ini menggunakan pendekatan kualitatif. Studi ini menemukan bahwa, masyarakat Islam Aceh hingga sekarang ini masih mengamalkan dan memercayai ajaran agama dan kepercayaan yang ditinggalkan oleh nenek moyang mereka. Mereka percaya dan menganggap bahwa objek tertentu mempunyai kekuatan gaib serta dapat memberikan pertolongan, suatu kepercayaan yang berbau bid'ah dan tahayul yang sudah menyatu menjadi bentuk kepercayaan yang tidak terpisahkan dalam keseharian masyarakat.
\end{abstract}

\begin{abstract}
Animism and Dynamism amongst the Achehnese Islamic Society. The Achehnese has been widely known to be religious society. Islamic religion plays an important role in leading the daily activities amongst the Achehnese. In reality, however, some pre Islamic believes still continue to developed in the society. This paper attempts to study the aspects of animism and dynamism believes in the Islamic society of Acheh, be they from the birth until death or the belief that is still preserved. This explorative research utilizes a qualitative approach. The study reveals that Achehnese Muslim thus far, though they adhere to religious teachings they still practise the beliefs inherited from their ancestors. They believe that certain object may have spiritual power and to be sought assistance, a belief categorized as innovation and imagination inherent in the form of belief indivisible in daily social lives.
\end{abstract}

Kata Kunci: teologi, kepercayaan, animisme dan dinamisme

\section{Pendahuluan}

Nanggroe Aceh Darussalam adalah teritorial bagian dari provinsi negara Indonesia. 
Dalam kehidupan sosial dan kepercayaan, masyarakat Nanggroe Aceh Darussalam, yang dalam hal ini adalah masyarakat yang tinggal dalam wilayah Kota Lhokseumawe dan Kabupaten Aceh Utara, masih mengamalkan amalan yang berkaitan dengan unsur ajaran agama Hindu dan kemudian diislamkan kembali. Dalam pelaksanaannya, keberagamaan mereka sangat dekat dan erat dengan ajaran agama Hindu. Tetapi, sekarang ini, ajaran Hindu tersebut telah diubah dan ditutupi seakan menjadi salah satu adat dan tradisi ajaran agama Islam. Tetapi, pesan yang disampaikan bertentangan ajaran agama Islam, sebab ajaran tersebut didasari kepada kepercayaan anamisme dan dinamisme. Antara lain adalah upacara tepung tawar seperti tepung tawar ucap syukur, tepung tawar mohon doa restu dan petunjuk dari Tuhan. Tepung tawar juga dapat memohon keberkahan, bahkan memohon maaf pada manusia apabila telah melakukan kesalahan. Contoh lain adalah kenduri. Masyarakat di wilayah Kota Lhokseumawe dan Kabupaten Aceh Utara juga dikenal dengan masyarakat yang selalu melaksanakan kenduri saat memperingati hari besar Islam seperti kenduri dalam memperingati Maulid Rasul, memperingati Isra' dan Mi'raj, Nisfu Sya'ban, Nuzul Qur'an, dan pada hari ke sepuluh Muharram.

Diketahui bahwa masyarakat Kota Lhokseumawe dan Aceh Utara, hingga kini masih menganut kepercayaan animisme, walaupun pada dasarnya telah menganut ajaran agama Islam yang telah disiarkan oleh para pedagang dan saudagar yang datang dari Tanah Arab. Masyarakat Kota Lhokseumawe dan Kabupaten Aceh Utara yang tinggal wilayah pedesaan hingga sekarang ini juga masih memercayai unsur animisme yang memercayai kekuatan yang gaib selain manusia. Kehidupan masyarakat Islam Aceh hingga kini tidak terlepas dari pengaruh unsur kepercayaan asing dan sudah menyatu dengan jiwa masyarakat setempat. Untuk menghapuskan sampai kepada tahap pemurnian akidah mereka, tentu memerlukan waktu yang lama dengan dukungan dan kerjasama pemerintahan setempat.

Sejarah mencatat bahwa Islam Aceh berasal dari negara India yang mayoritas penduduknya menganut ajaran Hindu Tantri Bhirawa. ${ }^{1}$ Dengan kondisi tersebut, terbentuklah suatu unsur kepercayaan yang sudah terjadi akulturasi antara ajaran Hindu dengan ajaran Islam. Ajaran yang bercorak akulturasi tersebut telah menjadikan suatu amalan bahkan menjadi suatu kepercayaan yang mirip dengan amalan ajaran Hindu, dan tidak didasari oleh ajaran Islam.

${ }^{1}$ Hindu Tantri Bhirawa mempunyai banyak aliran, baik dalam tradisi mistik Hindu maupun Buddha. Ajarannya ini berkenaan dengan istilah moksa, penyatuan diri dengan Yang Mutlak, melalui ajaran asketisme (ajaran yang menghindari suatu kenikmatan dunia seperti banyak makan dan berhubungan dengan istri) serta melanggar pantangan seperti makan daging, minum anggur, dan berhubungan suami istri. Maka pada akhir abad ke-13, termasuk tantrisme melanggar pantangan. Candi Sukuh di Surakarta adalah salah satu pusat pemujaan tantrisme kedua kelompok ini. Sedangkan tantrisme yang dipraktekkan Adityawarman di Sumatera merupakan bentuk yang lebih ekstrim lagi daripada aliran yang kedua. Lihat Braginsky, Satukan Hangat dan Dingin: Kehidupan Hamzah Fansuri, Pemikir dan Penyair Sufi Melayu (Kuala Lumpur: Dewan Bahasa dan Pustaka, 2004), h. 86-89; Sardono Kusumo, W., Aceh Kembali ke Masa Depan (Jakarta: IKJ Press. 2005), h. 272. 
Sebelum datangnya ajaran Islam di wilayah Kota Lhokseumawe dan Kabupaten Aceh Utara, masyarakat menganut kepercayaan animisme dan dinamisme. Mereka masih menganggap ada kekuatan yang tersembunyi di dalam benda mati dan kepada unsur kekuatan gaib di segala tempat yang boleh membantu mereka dalam segala hal. Tetapi, unsur kepercayaan terhadap anamisme dan dinamisme tidak bertahan lama di Aceh. Dengan masuknya ajaran Islam melalui jalur Gujarat, masyarakat pesisir Aceh mulai menerima dan memeluk ajaran Islam. Pada masa bersamaan, masyarakat pedalaman Aceh masih menganut animisme dan dinamisme, lalu akhirnya mereka menganut agama Islam, meskipun kepercayaan awal mereka masih dilaksanakan bahkan memengaruhi amalanamalan keislaman mereka. Akulturasi antara dua agama tersebut sulit diubah dan dimurnikan sesuai dengan ajaran Islam.

\section{Kepercayaan dalam Masyarakat}

Sejarah mencatat bahwa kawasan Aceh dikuasai oleh kerajaan Islam terkuat di Asia Tenggara sepanjang abad enam belas dan tujuh belas Masehi. ${ }^{2}$ Meskipun demikian, kehidupan masyarakat Aceh pedalaman ${ }^{3}$ masih begitu fanatik dengan aliran dan kepercayaan budaya Hindu, ${ }^{4}$ serta kepercayaan terhadap pohon-pohon besar, benda-benda

\footnotetext{
${ }^{2}$ Ahmad Daudi, Syeikh Nuruddin Ar-Raniry (Jakarta: Bulan Bintang, 1978), h. 6.

${ }^{3}$ Istilah "Aceh" berasal dari kata "Aca" yang artinya, saudara perempuan. Konon kata-kata tersebut berasal dari kata "Ba'si-aceh-aceh", seperti pohon beringin yang besar dan rindang, pohon tersebut sekarang ini jarang dijumpai. Lihat, Abu Bakar Aceh, "Tentang Nama Aceh," dalam Ismail Suni (peny.), Bunga Rampai Tentang Aceh (Jakarta: Bhratara Karya Aksara, 1980). Menurut cerita orang Aceh bahwa ada dua puteri kakak-beradik mandi di sungai dan sang adik sedang hamil. Mereka menemukan sebuah rakit pohon pisang yang di atasnya ada seorang bayi, bayi tersebut diambil oleh puteri yang tertua karena tidak mengandung; bayi itu dibawa pulang dan ia tidak keluar rumah selama empat puluh hari. Orang-orang kampung heran mendengar puteri yang tertua itu telah melahirkan, dan karena itu orang-orang kampung mengatakan "adoe yang mume, a yang ceh (adik yang hamil kakak yang melahirkan). Dari cerita inilah asal mula kata Aceh dan seterusnya menjadi sebutan resmi. Lihat, Wan Hussein Azmi, "Islam di Aceh: Masuk dan Berkembangnya Hingga Abad XVI," dalam A. Hasjmy (peny.) Sejarah Masuk dan Berkembangnya Islam di Indonesia (Bandung: Al-Ma'rif, 1993), h. 188-189; Yusny Saby, "Islam and Social Change: the of the Ulama in Acehnese Society (Disertasi Ph.D Temple University, 1995), h. 3-4; Kamaruzzaman BustamamAhmad, Islam Historis: Dinamika Studi Islam di Indonesia (Yogyakarta: Galang Press, 2002), h. 220. Undang-undang Nanggro Aceh Darussalam (NAD) disahkan dan disetujui oleh Dewan Perwakilan Rakyat Republik Indonesia (DPR-RI) tanggal 19 Juli 2001 sebagai undang-undang Otonomi Khusus Provinsi Daerah Istimewa Aceh. Sebelumnya lebih dikenal dengan nama Daerah Istimewa Aceh (D.I Aceh), karena berdasarkan surat Keputusan Perdana Menteri Republik Indonesia, Nomor. 1/ Missi/ 1959 terhitung mulai tanggal 26 Mei 1959 ditetapkan bahwa Daerah Swatentera Tingkat I Aceh dapat juga disebut Daerah Istimewa Aceh. Keputusan ini, disempurnakan lagi dengan Penetapan Presiden No. 6 tahun 1960, dan terakhir disesuaikan pula dengan undang-undang No. 18 tahun 1965, maka secara resmi Daerah Istimewa Aceh disebut Provinsi Daerah Istimewa Aceh. Monografi Daerah Istimewa Aceh (Banda Aceh: Universitas Syiah Kuala, 1972), h. 29; T. Alamsyah (peny.). Pedoman Umum Adat Aceh (Banda Aceh: Lembaga Adat dan Kebudayaan Aceh, 1991), h. 1.

${ }^{4}$ Seperti pohon beringin (ficus benjamina) dan pohon ketapang.
} 
Ridwan Hasan: Kepercayaan Animisme dan Dinamisme dalam Masyarakat Islam Aceh

dan kekuatan gaib Animisme ${ }^{5}$ dan Dinamisme. Mereka juga masih berpegang dan mengamalkan kepada ajaran agama yang telah ditinggalkan oleh orang-orang terdahulu, sekalipun pembawa ajaran tersebut bukan berasal dari agama Islam. Sampai sekarang, banyak peninggalan adat dan agama Hindu di kalangan masyarakat Kota Lhokseumawe dan Kabupaten Aceh Utara yang telah menjadi ajaran bidah, ${ }^{6}$ takhayul dan Khurafat, bahkan kepercayaan tersebut sudah berakar dalam masyarakat wilayah Kota Lhokseumawe dan Kabupaten Aceh Utara, John berkata:

"The cities of Achen if it may be so called is very spacious built in a wood so that we could not see a house till we were upon it, neither could we go into any place but we found houses and great concourse of people: so that I thinke the towne spreadeth over the whole land."

Animisme dan dinamisme adalah kepercayaan terhadap kekuatan yang luar biasa sebagaimana dikemukan oleh Max Muller dalam bukunya "The Growth of Religion." Apabila dianalisis lebih mendalam, sebenarnya al-Qur'an telah banyak membicarakan gejalagejala alam yang dahsyat dan luar biasa. Tetapi, gejala alam tersebut tidak untuk disembah dan ditakuti, sebab ini hanya sebagai gejala alam yang bersumber dari kekuatan Allah SWT. Dalam al-Qur'an dinyatakan bahwa:

Dan di antara tanda-tanda kekuasaan-Nya, Dia memperlihatkan kepadamu kilat untuk (menimbulkan) ketakutan dan harapan, dan Dia menurunkan hujan dari langit, lalu menghidupkan bumi dengan air itu sesudah matinya. Sesungguhnya padayang demikian itu benar-benar terdapat tanda-tanda bagi kaum yang mempergunakan akalnya (Q.S. al-Rûm/30: 24)

Dalam ayat lain yang Allah SWT. berfirman:

${ }^{5}$ Animisme ialah mempercayai bahwa setiap benda di bumi seperti kawasan tertentu, gua, pohon atau batu besar mempunyai jiwa yang mesti dihormati agar tersebut tidak mengganggu manusia, malah membantu mereka dari jiwa dan roh jahat dan juga dalam kehidupan seharian mereka. Lihat Amran Kasimin, Agama dan Perubahan Sosial (Kuala Lumpur: Dewan Bahasa dan Pustaka, 1991), h. 27.

${ }^{6}$ Bid'ah ialah amalan yang baru di dalam agama baik berupa akidah, ibadah, atau berupa sifat bagi ibadah yang belum pernah ada (terjadi) di masa Rasulullah SAW. Lihat Musthafa Kamal Pasha dan Ahmad Adaby Darban, Muhammmadiyah Sebagai Gerakan Islam (Yogyakarta: Pustaka SM, 1994), h. 286.

${ }^{7}$ Davis John, Purchas his Pilgrims, Vol. I (London: t.p., t.t.), h. 1625. 
Dan guruh itu bertasbih dengan memuji Allah, (demikian pula) para malaikat karena takut kepada-Nya, dan Allah melepaskan halilintar, lalu menimpakannya kepada siapa yang Dia kehendaki, dan mereka berbantah-bantahan tentang Allah, dan Dia-lah Tuhan Yang Maha keras siksa-Nya (Q.S. al-Ra'd/13: 13).

Kedua ayat tersebut di atas, Allah SWT. telah memperperlihatkan berbagai kekuasaan dan kehebatannya, salah satu contoh dengan menurunkan air dari langit serta dapat menghidupkan berbagai macam dan jenis tumbuhan dan kehidupan, bahkan dengan air pula dapat menghidupkan kembali berbagai jenis tumbuhan dan makhluk hidup lainnya. Allah SWT. juga menciptakan guruh dan malaikat turut bertasbih dari kebesarannya.

Menurut Durkheim, ${ }^{8}$ sistem agama primitif seperti animisme dan dinamisme terdapat dalam masyarakat yang sangat sederhana, dan sistem agama tersebut dapat dijelaskan tanpa harus terlebih dahulu menjelaskan elemen-elemen lain dari agama yang lebih tua darinya. Ia mengatakan bahwa agama primitif lebih dapat membantu dalam menjelaskan hakikat religius manusia dibandingkan dengan bentuk agama lain yang datang setelahnya, sebab agama primitif mampu memerlihatkan aspek kemanusiaan yang paling fundamental dan permanen dalam memahami inti dari kepercayaan tersebut. Adapun agama dalam arti obyektif ialah segala apa yang dipercayai, sedangkan agama dalam arti subyektif ialah dengan cara bagaimana manusia berdiri di hadapan Tuhan dan bagaimana ia harus mentaati segala perintah dan meninggalkan segala larangan-Nya.

\section{Unsur Animisme}

Pengertian dari Animisme cukup banyak. Kata animisme berasal dari bahasa Latin "anima" yang berarti "roh". ${ }^{9}$ Animisme adalah suatu kepercayaan terhadap makhluk halus dan roh, serta keyakinan seperti ini sudah banyak dianut oleh bangsa-bangsa yang belum bersentuhan ataupun belum pernah menerima ajaran yang berdasarkan daripada agama samawi (wahyu). ${ }^{10}$ Adapun karakteristik masyarakat yang menganut paham ini, antara lain adalah mereka selalu memohon perlindungan dan permintaan sesuatu kepada rohroh, misalnya untuk penyembuhan penyakit, sukses dalam bercocok tanam, terhindar dari gangguan hama tanaman, hidup rukun, berhasil dalam berburu, selamat dalam perjalanan jauh dan berperang, terhindar dari gangguan bencana alam seperti banjir, gunung meletus, gempa bumi, kebakaran, dan gangguan cuaca; mudah dalam melahirkan, masuk surga

${ }^{8}$ Durkheim, dilahirkan pada tahun 1858 di kota Epinal dekat Strasbourg, daerah Timur Laut Perancis. Ayahnya seorang pendeta Yahudi. Durkheim adalah seorang pemuda yang sangat dipengaruhi oleh guru-guru sekolahnya yang beragama Katolik Roma, walaupun ayahnya seorang pendeta Yahudi. Daniel L, Seven Theories of Religion (New York: Oxford University Press, 1996), h. 91-92.

${ }^{9}$ Caroline Pooney, African Literature, Aninism and Politic (London: Routledge, 2001), h. 10.

${ }^{10}$ Zakiah Daradjat, (peny.), Perbandingan Agama I (Jakarta: Bumi Aksara, 1996), h. 28. 
setelah melahirkan, selamat saat membangun dan masuk rumah baru, serta mencapai kedudukan. ${ }^{11}$ Inti dari pemahaman animisme ialah mempercayai bahwa setiap benda di bumi seperti laut, gunung, hutan, gua, dan kuburan mempunyai jiwa yang harus dihormati dan dijunjung agar jiwa tersebut tidak mengganggu manusia, bahkan dapat membantu mereka dalam kehidupan untuk menjalankan aktifitas kesehariannya. ${ }^{12}$

Ciri utama kepercayaan animisme adalah percaya kepada kewujudan roh. Di antaranya adalah penganut kepercayaan ini meyakini bahwa roh seseorang yang telah mati akan bergentayangan ibarat tanpa tuan, menganggu mereka, bahkan kembali datang mengunjungi mereka juga. Sebab itu, mereka mengadakan acara ritual kepada arwah tersebut pada hari ketiga, ketujuh, dan keseratus. Selain itu, mereka percaya bahwa tumbuhtumbuhan dan binatang memiliki kekuatan gaib. Dalam hal ini, penganut animisme melakukan pemujaan terhadap kekuatan roh tersebut yang dipimpin oleh pawang. Tujuannya adalah untuk memeroleh kebaikan dan terhindar dari bencana alam. Setelah ajaran Islam masuk ke daerah Aceh, segala kepercayaan tersebut perlahan-lahan menghilang, tetapi mulai disesuaikan dengan ajaran Islam.

\section{Unsur Dinamisme}

Istilah dinamisme berasal dari bahasa Yunani, yaitu dunamos. Dalam bahasa Inggris disebut dynamic, artinya adalah kekuatan, daya, kekuatan atau khasiat. Dalam hal ini, dinamisme adalah kepercayaan terhadap benda-benda di sekitar manusia karena diyakini memiliki kekuatan yang gaib. Dengan kata lain, dinamisme adalah keyakinan terhadap kekuatan yang berada dalam zat suatu benda dan diyakini mampu memberikan suatu manfaat dan marabahaya. Kesaktian itu bisa berasal dari api, batu-batuan, air, pohon, binatang, bahkan manusia. Unsur dinamisme lahir dari rasa ketergantungan manusia terhadap daya dan kekuatan lain yang berada di luar dirinya. Setiap manusia akan selalu merasa butuh dan berharap kepada zat lain yang dianggapnya mampu memberikan berbagai pertolongan dengan kekuatan yang dimilikinya. Manusia tersebut mencari zat lain yang akan ia sembah, karena ia merasa tenang dan nyaman jika ia selalu berada dekat zat tersebut. ${ }^{13}$

Dalam konteks ini, sebagian masyarakat Kota Lhokseumawe dan Kabupaten Aceh Utara masih memercayai benda-benda tertentu yang mempunyai kekuatan yang luar biasa seperti kepercayaan terhadap kekuatan batu cincin. Mereka menyakini bahwa cincin tersebut memiliki kekuatan gaib yang dapat menghindarinya dari berbagai bahaya. Selain

${ }^{11}$ Alan Barnard and Jonathan Spencer, Encyclopaedia of Social Cultural Anthropology (London: Rotledge, 1996), h. 595.

${ }^{12}$ A.G. Pringgodidgo (peny.), Ensiklopedi Umum (Jakarta: Yayasan Dana Buku Franklin, 1973), h. 74.

${ }^{13}$ Edward B. Tylor, Primitive Culture: Research into the Development of Mythology, Philosophy, Religion, Langguage, Art and Custom (New York: Brentano's Publishers, t.t.), h.160. 
itu, mereka juga masih memercayai kekuatan dalam rencong. Mereka juga memercayai jenis-jenis jin dalam berbagai bentuk, ${ }^{14}$ sepertijen apui, ${ }^{15}$ si bujang itam, ${ }^{16}$ burong, ${ }^{17}$ geunteut,${ }^{18}$ beunot, dan burong tujoh. ${ }^{19}$ Mereka juga memercayai bahwa roh orang yang telah meninggal karena dibunuh, mati berdarah, mati tenggelam, dan mati jatuh dari pohon kayu akan menjelma menjadi hantu. Masyarakat juga masih memercayai bahwa ketika seseorang selalu berbuat jahat selama hidupnya lalu mati, rohnya akan menjelma dalam bentuk babi atau kera yang keluar dari liang kuburnya. Sebaliknya, orang alim akan menjadi "keramat," ${ }^{20}$ dan menjelma dalam bentuk harimau atau ular yang baik perangainya. ${ }^{21}$ Jelmaan ini akan melindungi kampung di sekitar kuburan ${ }^{22}$ dan biasanya digunakan sebagai tempat bernazar (meukaoy). Kendati dalam hadis ada anjuran untuk berziarah ke kuburan, ${ }^{23}$ tetapi pelaksanaan ajaran bercorak animisme dan dinamisme tersebut bertentangan dengan ajaran syariat Islam.

Masyarakat Aceh sangat taat dalam menjalankan acara ritual keagamaan, bahkan sangat fanatik terhadap agamanya. Sebab, Islam sudah mendarahdaging dalam diri masyarakat Aceh. Tetapi, tidak semua masyarakat Aceh melaksanakan semua ajaran Islam sejati dan murni. Banyak masyarakat Aceh belum memahami ajaran Islam yang sebenarnya. Meskipun demikian, mereka sangat peka terhadap pengaruh kepercayaan lain, baik dari dalam maupun dari luar daerah, apabila bertentangan dengan ajaran al-Qur'an dan hadis, maka mereka langsung menolak keberadaannya sehingga ajaran tersebut tidak diterima. ${ }^{24}$

${ }^{14}$ Lihat Departemen. P dan K. Adat Istiadat Daerah Provinsi Daerah Istimewa Aceh (Banda Aceh: Departemen P dan K, 1990), h. 99.

${ }^{15} \mathrm{Jin}$ tersebut tampak seperti cahaya api di waktu malam hari.

${ }^{16}$ Dilukiskan sebagai tokoh kasar, angker, dan jahat serta mengerikan.

${ }^{17}$ Penjelmaan dari roh orang yang meninggal dalam melahirkan, sebagai seorang wanita yang berpakaian serba putih berkuku panjang, serta berlobang di bagian belakang. Lihat Departemen. P dan K, Adat Istiadat, h. 100.

${ }^{18}$ Geunteut, sejenis makhluk halus sebagai jin, yang mempunyai tubuh yang tinggi dan besar. Beunot, sebangsa makhluk halus sebagai penganggu yang sering menghimpit orang yang sedang tidur.

${ }^{19}$ Digambarkan sebagai tujuh orang bersaudara yang mati melahirkan.

${ }^{20}$ Lihat Winstedt, A History of Malaya (Singapore: Royal Asiatic Society, 1935), h. 264. Klasifikasi keramat di kalangan orang Melayu terbagi kepada beberapa golongan: (1). Unsur benda, misalnya batu, puncak bukit, tanjung, air pusar dan sebagainya, (2). Harimau dan buaya yang suci, (3). Kuburan dukun, (4). Kuburan orang yang menjumpai sesuatu petempatan, (5). Kuburan ulama, (6). Ulama Islam yang masih hidup. Lihat Kasimin, Agama dan Perubahan Sosial, h. 91.

${ }^{21}$ Departemen P. dan K., Adat Istiadat, h. 100.

${ }^{22}$ Kebanyakan kuburan keramat letaknya terpisah dari kawasan perkuburan biasa. Meskipun kuburan yang asli tidak memiliki jasad orang keramat. Orang yang kuburannya keramat tidak pernah mati, tetapi hanya kelihatan mati dan dikatakan kembali kepada Tuhan. Kuburan ini hanyalah sebagai simbol kekudusan keramat itu. Kasimin. Agama dan Perubahan Sosial, h. 91.

${ }^{23}$ Dalam sebuah hadis dinyatakan yang artinya "barang siapa yang ingin melakukan ziarah kubur lakukanlah, untuk mengingatkan dirimu kepada akhirat." Lihat, Muhammad 'Îsâ bin Surah al-Tirmidzî, Sunan al-Tirmizî, Jilid II (Kuala Lumpur: Victory Agencie, t.p., 1993), h. 379.

${ }^{24}$ Bahan-bahan Seminar, Sejarah Masuk dan Berkembangnya Islam di NAD (Banda Aceh: MUI-NAD. Banda Aceh, 1978), h. 9. 
Akulturasi budaya di Aceh menghasilkan corak beragama yang unik, meskipun sebagian ritual agamanya negatif. Budaya negatif yang dipertahankan dalam masyarakat Aceh sampai sekarang adalah upacara tolak bala antara lain Rabu Abeh atau Mandi Safar. Upacara tolak bala dilaksanakan pada hari Rabu terakhir bulan Safar. ${ }^{25}$ Pada hari tersebut, semua masyarakat harus berkumpul untuk memasak dan makan bersama. Sebagian masakan dipisahkan dan ditinggalkan di satu tempat tertentu atau di atas pohon kayu tertentu. Menurut kepercayaan mereka, Rabu Abeuh ${ }^{26}$ dilakukan untuk mengusir roh jahat, karena ia dapat membinasakan masyarakat. Upacara tersebut dilaksanakan di tepi pantai. Jelas bahwa ritual ini sangat bertentangan dengan syariat Islam, terutama tidak sesuai dengan firman Allah SWT. yang termaktub dalam al-Qur'an:

Jadilah engkau pema'af dan suruhlah orang mengerjakan yang ma'ruf, serta berpalinglah dari pada orang-orang yang bodoh (Q.S. al-A'râf/7: 199).

Menurut ayat tersebut di atas, Allah SWT. memerintahkan hambanya untuk mengerjakan amalan yang baik dari segala sesuatu yang mudah dan tidak memberatkan dan Allah SWT. memerintahkan agar menghindari daripada amalan orang-orang yang jahil. Dalam hal ini, sebagian ulama. ${ }^{27}$ Aceh belum membuat suatu perubahan apalagi menghapuskan amalan khurafat. Mereka hanya diam dan belum berani mengadakan perubahan. Mereka percaya amalan tersebut dapat mendatangkan syafaat apabila dilaksanakan, dan akan mendatangkan mudarat apabila ditinggalkan, dalam wilayah Kota Lhokseumawe dan Kabupaten Aceh Utara, kepercayaan tersebut menjadi bagai tradisi ritual tahunan dan selalu untuk dirayakan, meskipun bertentangan dengan al-Qur'an dan hadis.

Di wilayah Kota Lhokseumawe dan Kabupaten Aceh Utara, beberapa aliran dan gerakan

${ }^{25}$ Departemen P. dan K., Adat Istiadat, h. 107.

${ }^{26} \mathrm{Rabu}$ Abeuh merupakan hari Rabu terakhir pada bulan Shafar.

${ }^{27}$ Kata "ulama" berasal dari bahasa Arab, jamâ' dari kata 'alîm yaitu orang yang mengetahui. Ulama adalah kumpulan umat yang mendalami ilmu-ilmu agama, juga dijadikan tempat umat untuk meminta fatwa. Pengakuan ini diberikan Allah kepada mereka dengan melebihkannya beberapa derajat. Lihat, Q.S. al-Mujâdalah: 11. Di daerah Aceh ada dua tipe ulama. 1) ulama tradisional, yaitu ulama yang selalu berpikir dan berpegang teguh pada kitab Allah dan menguasai secara baik hukum syara', juga memiliki sifat tawâdhu' dan istiqâmah kepada Allah. Ia disebut juga ulama Dayah (pondok), kampung atau ulama ahkirat. 2) Ulama modern yang mampu tampil di depan sebagai Imam dan rakyat sebagai makmumnya. Di samping memiliki kedalaman ilmu agama dengan asas akhlak yang tinggi, juga mereka dapat menerima perubahan yang terjadi sebagai dampak kemajuan ilmu pengetahuan dan teknologi. Lihat, Badruddin Subqi, Dilema Ulama dalam Perubahan Zaman (Jakarta: Gema Insani Press, 1995), h. 56. 
modern muncul seperti Muhammadiyah, ${ }^{28}$ Ahl Sunnah wa al-Jamaah, ${ }^{29}$ dan Al Washliyah. Gerakan-gerakan tersebut memang cukup berperan dalam memperbarui kondisi masyarakat Aceh terutama dalam bidang akidah, akhlak, ibadah dan muamalah, ${ }^{30}$ pendidikan, dan politik. Masyarakat Aceh juga memeroleh bimbingan dari Majelis Permusyawaran Ulama (MPU), ${ }^{31}$ suatu lembaga badan fatwa untuk dapat memberikan dan menampung aspirasi masyarakat Aceh, dan fungsinya sama dengan Majlis Ulama Indonesia (MUI), ${ }^{32}$ meskipun ada perbedaan antara kedua lembaga ini terutama dalam program kerja.

\section{Kepercayaan Animisme Masyarakat Aceh}

Ada beberapa upacara ritual keagamaan dalam masyarakat yang tinggal di wilayah Kota Lhokseumawe dan Kabupaten Aceh Utara yang masih melaksanakan dan mengamalkan berbagai ritual kepercayaan, bahkan hingga saat ini ritual tersebut selalu diamalkan, seperti ritual tepung tawar, ritual kelahiran bayi, ritual mencukur rambut bayi, dan ritual sirih pertunangan.

\section{Ritual Tepung Tawar (Peuseujuk)}

Peusijuk adalah dari asal kata sijuk (dingin) yang ditambah pada kata awal peu" sehingga menjadi kata peusijuk, artinya adalah pendingin atau mendinginkan. Makna peusijukadalah mengharapkan yang baik. Peusijuk adalah lambang untuk peusijuk leum beng peurisee (menjatuhkan lembing dan perisai), satu adat Aceh yang berfungsi dan ditetapkan sebagai pelengkap salah satu hukum Adat. ${ }^{33}$

Adat tepung tawar (peusijuk) merupakan adat yang sering diamalkan. ${ }^{34}$ Istilah lainnya

${ }^{28}$ Muhammadiyyah didirikan oleh KH. Ahmad Dahlan. Ia lahir di kampung Kauman, Yogyakarta pada tahun 1868 M. Didirikan pada tanggal, 8 Zulhijjah $1330 \mathrm{H}$ atau 18 November 1912 M. Pasha dan Darban, Muhammadiyah sebagai Gerakan Islam, h. 109.

${ }^{29}$ Ahli Sunah Waljamaah adalah kelompok yang berpedoman pada Sunnah Rasul. Ataupun, arti sunnah menurut para ahli hadis adalah apa yang diterima dari Rasulullah SAW berupa perkataan, perbuatan, persetujuan, sifat peribadinya atau jasmaninya serta perjalanan hidupnya, baik selama sebelum diutus menjadi Rasul ataupun sesudahnya. Dengan pengertian ini maka menurut sebagian ulama, sunnah adalah sama dengan hadis." Lihat, Musthafa al-Siba'i, Al-Sunnah wa Makânatubâ fì Tasyri al-Islâmi (t.t.p.: t.p, t.t.), h. 53.

${ }^{30}$ Pasha dan Darban, Muhammadiyah sebagai Gerakan Islam, h. 311.

${ }^{31}$ Dalam Peraturan Daerah No. 3 tahun 2000 tentang Pembentukan Organisasi dan Tata Kerja Majlis Permusyawaratan Ulama (MPU) Provinsi Daerah Istimewa Aceh pada tanggal 14 Juni 2000 (lembaga daerah No. 23 tanggal, 22 Juni 2000). Rusdi Sufi (peny)., Adat Istiadat Masyarakat Aceh (Banda Aceh: t.p., t.t.), h. 37.

${ }^{32}$ Ismuha, Sejarah Singkat Ulama Propinsi Daerah Istimewa Aceh (Banda Aceh: Sekretariat MUI Prvinsi D.I Aceh, 1983), h. 1.

${ }^{33}$ Badruzzaman Ismail, Wawancara, 22 Juli 2006.

34"Upacara Peusijuk," (Lhokseumawe: Lembaga Adat dan Kebudayaan Aceh (LAKA), 1988). h. 35 . 
Ridwan Hasan: Kepercayaan Animisme dan Dinamisme dalam Masyarakat Islam Aceh

adalah tepung tawar yang merupakan salah satu adat yang dilaksanakan pada acara tertentu, mulai dari waktu senang sehingga waktu susah dan dukacita. Tepung tawar merupakan salah satu kegiatan penting sebagai ungkapan terima kasih dan rasa syukur kepada Allah SWT., karena telah mendapatkan suatu rahmat dan terlindung dari segala kesusahan dan rintangan yang akan menimpanya. ${ }^{35}$

Dalam adat dan tradisi masyarakat Kota Lhokseumawe dan Kabupaten Aceh Utara, bahwa amalan ritual tepung tawar (peuseujuk) masih dipertahankan dan diamalkan. Apabila ada sebuah acara ritual, maka tepung tawar menjadi amalan yang sakral dan harus dilakukan menurut kepercayaan masyarakat setempat supaya mendapatkan keberkatan dan perlindungan dari Allah SWT. Acara ritual tepung tawar disertai dengan membaca doa. ${ }^{36}$

Tradisi tepung tawar merupakan amalan orang Jahiliah masa lalu, jauh sebelum datangnya ajaran Islam di Aceh. Pada umumnya, sebagian ulama Aceh berpendapat bahwa ritual tepung tawar berasal dari Rasulullah SAW. yang pernah memercik air ke atas kepala Fathimah yang kemudian alasan tersebut dijadikan legalitas hukum. Kemudian, sebagian ulama tersebut berpendapat bahwa hukum melaksanakan tepung tawar adalah boleh, karena Rasulullah sendiri pernah melaksanakannya. ${ }^{37}$ Tetapi, apabila ditanya mengenai status hadis tersebut sahih atau tidak, ulama setempat tidak dapat memberikan penjelasan mengenai kedudukan hadis tersebut.

Berdasarkan data yang telah didapatkan di lapangan menunjukkan bahwa mayoritas masyarakat pedesaan cenderung dan mengarah kepada pendapat bahwa kepercayaan tepung tawar menghasilkan keberkatan dalam hidup. Sedangkan mayoritas masyarakat perkotaan tidak yakin jika tepung tawar dapat memberikan keberkatan dalam hidup.

\section{Ritual Kelahiran Bayi}

Menurut kepercayaan adat masyarakat Aceh, apabila seorang istri sudah melahirkan, pihak keluarga dengan senang hati memberikan sejenis hadiah kepada yang sedang hamil (mablien). Hadiah tersebut antara lain sirih setapak (bahan-bahan sirih), pakaian salinan (satu set pakaian), dan uang secukupnya. ${ }^{38}$ Ketika upacara tersebut selesai, mereka akan memberikan hadiah untuk bidan berupa pakaian salinan, uang secukupnya, uang penebus cincin suasa, beras dua bambu, padi dua bambu (segantang), ketan kuning, ayam panggang, dan satu ekor ayam yang hidup sebagai tanda ucapan terima kasih kepada bidan karena telah memberikan pelayanan yang baik kepada keluarga yang telah melahirkan anak

${ }^{35}$ Ibid. h. 35.

36

${ }^{37}$ Tgk. H. Mustafa Puteh, Ketua Majlis Permusyawatan Ulama (MPU) Kabupaten Aceh Utara, Wawancara, 29 Juni 2006.

${ }^{38} \mathrm{~T}$. Syamsuddin, Adat Istiadat Daerah Provinsi Daerah Istimewa Aceh (Jakarta: Departeman Pendidikan dan Kebudayaan, 1997), h. 125-128. 
bayi tersebut. Kemudian bayi itu dipangku oleh semua peserta upacara secara bergantian dengan mengucapkan ucapan yang sama sampai selesai. Kemudian bayi tersebut dibawa turun ke tanah melalui sebuah tangga, dan kemudian bayi tersebut dibawa ke tempat pemandian atau sungai untuk dimandikan dengan upacara tertentu. Ritual tersebut masih diamalkan oleh masyarakat Aceh Utara dan Lhokseumawe, dan memang sudah menjadi suatu adat dan tradisi sejak masa lampu, bahkan tampak sulit mengubah keadaan tersebut.

\section{Ritual Mencukur Rambut Bayi}

Ritual mencukur rambut usia bayi dilakukan ketika bayi berumur sekitar enam bulan. Ritual ini telah menjadi semacam tradisi yang harus dilaksanakan dan diamalkan dalam masyarakat Aceh. Acara ritual ini bahwa melibatkan sebagian tokoh dari masyarakat, tokoh adat dan para ulama. ${ }^{39}$ Biasanya, ritual ini memakai alat dan kelengkapan tertentu seperti telur ayam mentah, madu lebah (ie unoe), buah kurma dan jenis makanan lain yang berzat manis dan bergizi. Semua perlengkapan tersebut diserahkan kepada pihak besan yang diterima oleh salah seorang wanita sebagai pemuka adat setempat. ${ }^{40}$

Dalam ritual tersebut, biasanya diletakkan pada sebuah dulang (dalong) bertutup tudung saji (sangee) yang di dalamnya berisi ketan kuning (bu leukat kunfeng) dan panganan lain seperti ikan kayu (keumamah) yang telah dimasak menjadi gulai atau adunan tepung (tumpoe) atau daging. Setelah kenduri selesai dan para undangan pulang, acara dilanjutkan oleh ahli keluarga, tetangga, para pemuka kampung, dan pemuka adat.

Sementara bayi yang telah selesai dicukur rambutnya akan ditidurkan di atas kasur kecil yang bertutup hiasan kain warna-warni. Lali, bayi dibawa ke suatu ruangan di mana orang alim terkemuka (teungku sagoe) telah menunggunya. Kepada menantunya memberikan uang sembahan (seuneumah), yang diikuti dengan tindakan yang sama oleh ahli keluarga dan orang tua daripada kaum wanita lain yang hadir di tempat tersebut. Tamu lelaki membawa hadiah berupa tembakau, sirih, buah-buahan dan ikan yang disebut barang pasar (barang peukan), gunanya sebagai pengikat tali persaudaraan dan meringankan beban biaya daripada pihak keluarga tersebut. ${ }^{41}$

\section{Ritual Sirih Pertunangan}

Acara sirih pertunangan lebih dikenal juga dengan acara tukar cincin. Ritual ini telah menjadi suatu kebiasaan bagi kaum lelaki (calon pengantin lelaki) memasukkan cincin ke jari wanita yang akan dinikahinya. Amalan dan pelaksanaan ritual ini belum

\footnotetext{
${ }^{39}$ Nama lengkapnya adalah Tgk. H. Syamaun Risyad, Lc.

${ }^{40}$ Alamsyah, Pedoman Umum Adat Aceh, h. 81.

${ }^{41}$ Ibid. h. 81.
} 
Ridwan Hasan: Kepercayaan Animisme dan Dinamisme dalam Masyarakat Islam Aceh

pernah ada dalam ajaran Islam, dan menurut pandangan hukum Islam adalah haram hukumnya menyentuh tangan wanita yang bukan mahramnya dan merupakan suatu perbuatan dosa. ${ }^{42}$

Bertukar cincin bukanlah tradisi budaya dan ajaran Islam, melainkan cara bangsa Eropa yang mendapat pengesahan dari Dewan Gereja. Jadi, amalan tukar cincin mulanya bukan cara umat Kristen, melainkan warisan peradaban bangsa Romawi yang menganut ajaran agama Kristen. Amalan tersebut juga merupakan amalan yang menyerupakan amalan orang Nasrani, dan ini bertentangan dengan ajaran Islam, sedangkan Rasulullah SAW. sendiri tidak pernah menyentuh tangan wanita selain dari muhrimnya atau dengan istrinya. ${ }^{43}$ Rasulullah SAW. juga memberikan gambaran seseorang telah ditusuk dengan jarum panas ditelapak tangannya lebih baik perbuatan tersebut daripada menyentuh tangan seorang wanita selain muhrimnya.

\section{Unsur Kepercayaan Dinamisme Masyarakat Aceh}

Dalam kepercayaan masyarakat Aceh, ada sejumlah upacara ritual dan kepercayaan masih diyakini membawa keberkatan dan perlindungan seperti pemujaan tempat dan benda mati, pengeramatan kuburan, dan bernazar (meukaoi).

\section{Pemujaan Tempat dan Benda Mati}

Diketahui bahwa masyarakat Aceh masih ada yang memuja tempat-tempat tertentu dan benda mati karena dianggap masih mempunyai nilai mistik. Menurut mereka, tempattempat tertentu ataubenda mati tertentu dapat menolong mereka meraih kebaikan dan dan menyelamatkan mereka dari bahaya dan bencana. Tradisinya, upacara ritual selalu diiringi upacara makan-makan bersama. Amalan ini serupa dengan amalan orang Hindu yang masih diamalkan. ${ }^{44}$

Masyarakat Kota Lhokseumawe dan Kabupaten Aceh Utara juga masih ada yang melaksanakan pemujaan pantai di mana para penangkap ikan memberi hadiah kepada penjaga laut untuk mendapat perlindungan. Amalan lain adalah amalan untuk menentukan dan memeroleh hasil padi yang lumayan, serta amalan Mandi Safar (mano safa) atau upacara bersuci. ${ }^{45}$ Upacara-upacara tersebut masih diyakini dan dilaksanakan oleh masyarakat Lhokseumawe dan Kabupaten Aceh Utara.

\footnotetext{
${ }^{42}$ Syams al-Dîn al-Zahâbî. Al-Kabâ'ir (Beirut: Dâr al-Fikr, t.t), h. 217.

${ }^{43}$ H.R. Bukhârî, al-Tirmizî dan Ahmad.

${ }^{44}$ R. Hefner, Hindu Javanese: Tengger Tradition and Islam (Princeton: Princeton University Press, 1984), h. 104-105.

${ }^{45}$ Joginder Singh Jessy, Malaysia Singapora dan Brunai 1400-1965 (Selangor: Longman,
} 1975), h. 53. 
MIQOT Vol. XXXVI No. 2 Juli-Desember 2012

Harus diketahui bahwa amalan tersebut bertentangan dengan agama Islam dan merupakan amalan syirik. ${ }^{46}$ Amalan tersebut sangat membahayakan sebuah keyakinan dan akidah seorang mukmin sejati, sebagaimana firman Allah SWT.

Sesungguhnya Allah tidak mengampuni dosa mempersekutukan (sesuatu) dengan Dia, dan dia mengampuni dosa yang selain syirik bagi siapa yang dikehendaki-Nya. Barangsiapa yang mempersekutukan (sesuatu) dengan Allah, maka sesungguhnya ia telah tersesat sejauh-jauhnya (Q.S. al-Nisâ'/4: 116).

Berdasarkan ayat tersebut, Allah SWT menyatakan bahwa Dia tidak akan mengampuni dosa orang-orang syikir kepadanya, atau dosa orang yang melakukan amalan yang mengandung unsur syirik sehingga dapat menyekutukannya.

\section{Pengeramatan Kuburan}

Dalam hal ini, beberapa kuburan ulama telah dikeramatkan oleh masyarakat Aceh. Apabila mereka memiliki sesuatu hajat, mereka akan datang dan duduk dekat kuburan tersebut. ${ }^{47}$ Atau siapa yang ingin melaksanakan nazar, maka ia harus pergi ke tempat tersebut disertai dengan melaksanakan salat sunat dua rakaat di kuburan tersebut. ${ }^{48}$ Tetapi jelas bahwa amalan tersebut adalah sebagai bentuk pelanggaran nyata terhadap ajaran Islam sebagaimana diajarkan Rasulullah SAW. Sebagian masyarakat yang tinggal di wilayah Kota Lhokseumawe dan Aceh Utara, masih mengamalkan adat kebiasaan seperti meletakkan sesuatu seperti kain putih sebanyak tujuh meter dan disertai dengan meletakkan uang sekadarnya. Amalan tersebut masih diamalkan oleh penduduk perkampungan dan penduduk pesisir pantai. Umumnya, mereka kurang memiliki pengetahuan agama yang mendalam sehingga masyarakat tersebut masih melaksanakan berbagai amalan yang mengarah pada perbuatan khurafat dan tahayul.

Kepercayaan tersebut masih diamalkan oleh masyarakat yang tinggal wilayah Kota Lhokseumawe dan Aceh Utara. Tujuannya adalah untuk meminta sesuatu kepada Allah

\footnotetext{
${ }^{46}$ Pertama, syirik akbâr, yaitu menyekutukan Allah SWT. dengan sesuatu makhluk, bila berdosa ia memohon pertolongan dari makhluk, mengharapkan kepada sesuatu ataupun kasihkan sesuatu itu seperti kasih kepada Allah SWT. atau menyembelih atau kurban kepadanya, atau bernazar kepadanya. Kedua, syirik asgâr, yaitu mengerjakan sesuatu amalan dengan riya atau mengerjakan sesuatu bukan karena Allah SWT. semata-mata.

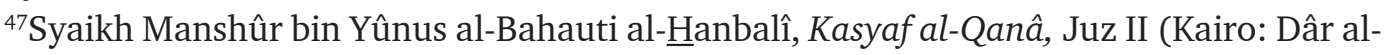
Mishriah, 1987), h. 186.

${ }^{48}$ Wahbah Zuhaili, Al-Fiqh al-Islâmi wa Adillatuhu, Juz II (Beirut: Dâr al-Fikr al-Mu'âsir, 1997), h. 1555. Amalan tersebut sangat bertentangan dengan ajaran Islam yang sebenarnya.
} 
Ridwan Hasan: Kepercayaan Animisme dan Dinamisme dalam Masyarakat Islam Aceh

SWT. melalui perantara kuburan orang yang telah dikeramatkan ataupun kubur para wali. Padahal, amalan tersebut bertentangan dengan syariat Allah SWT. sebagaimana firman.

Dan bahwasanya ada beberapa orang laki-laki di antara manusia meminta perlindungan kepada beberapa laki-laki di antara jin, maka jin-jin itu menambah bagi mereka dosa dan kesalahan (Q.S. al-Jinn/72: 6).

Berdasarkan ayat tersebut, amalan yang dilarang Islam adalah memuja dan meminta pertolongan kepada para jin agar supaya terhindar dari bencana, banyak rezeki, mendapatkan keturunan, dan memohon kepada Allah SWT.

\section{Bernazar (Meukaoi)}

Bernazar ${ }^{49}$ sudah menjadi dalam tradisi masyarakat Islam Aceh. Ketika mereka menginginkan sesuatu dan ingin dikabulkan oleh Allah SWT., sebagian mereka melaksanakan nazar di tempat dan masa tertentu seperti di kuburan keramat. Amalan ini adalah amalan yang dilakukan oleh orang-orang Jahilliah terdahulu. ${ }^{50}$ Meskipun demikian, bahwa amalan tersebut masih diamalkan oleh sebagian besar masyarakat yang tinggal dalam wilayah Kota Lhokseumawe dan Kabupaten Aceh Utara.

Amalan bernazar ataupun membayar nazar telah lama diamalkan dalam sejarah manusia, bahkan hukum untuk membayar nazar adalah wajib. Misalnya berpuasa nazar, maka wajib untuk menunaikannya. ${ }^{51}$ Ketentuan nazar tersebut adalah bahwa ia beragama Islam dan tidak sah bernazar bagi anak kecil, orang gila dan orang kafir. ${ }^{52}$ Sementara amalan yang berhubungan dengan akidah dan ibadah mempunyai dasar yang kuat, sebagaimana firman Allah:

(Ingatlah), ketika isteri 'Imran berkata: "Ya Tuhanku, sesungguhnya aku menazarkan kepada

\footnotetext{
${ }^{49}$ Nazar ada dua. Pertama, nazar dengan penyembelihan atau korban ketika mendapat sesuatu nikmat atau menolak sesuatu bala misalnya seorang berkata "Jika Allah SWT. menyembuhkan sakitku, aku akan beri makan tiga orang miskin, atau jika Allah SWT. kabulkan cita-citaku maka aku akan membacakan Surat Yasin. Kedua, nazar mutlak yaitu nazar tanpa syarat. Misalnya seorang berkata "bagi Allah SWT. ke atasku sembahyang sunat dua rakaat," maka nazar itu wajiblah ditunaikan. Sayyid Sabiq, Fiqh al-Sunnah, Jilid III (Beirut: al-Kitâb al-'Arabî, 1973), h. 37-38; Wahbah Zuhailî, Al-Fiqh al-Islâmi wa Adillatuhu, Juz IV (Beirut: Dâr al-Fikr al-Mu'âsir, 1997), h. 2552.

${ }^{50}$ Mahmûd Syaltût, Al-Fatâwâ: Dirâsât al-Musyaqqilat al-Muslim al-Mu'sir fî Hayâtihi alYaumiyyah wa al-Mat (Kairo: Dâr al-Qalam, t.t.). h. 216.

51

52Zuhailî, Al-Fiqh al-Islâmi wa Adillatuh, Juz IV, h. 2552.
} 
MIQOT Vol. XXXVI No. 2 Juli-Desember 2012

Engkau anakyang dalam kandunganku menjadi hamba yang saleh dan berkhidmat (di Baitul Maqdis). Karena itu terimalah (nazar) itu dari padaku. Sesungguhnya Engkaulah Yang Maha Mendengar lagi Maha Mengetahui (Q.S. Âli ‘Imrân/3: 35).

Kandungan ayat tersebut di atas menjelaskan bahwa amalan bernazar bila dilihat dalam sejarah sudah lama amalan tersebut dilaksanakan oleh umat manusia ketika itu, agar keinginannya dikabulkan oleh Allah SWT. Sebagai contoh, ketika istri Imran menginginkan anaknya ketika dalam kandungannya agar kelak akan menjadi anak yang saleh dan berkhidmat di Baitul Maqdis.

\section{Penutup}

Berdasarkan uraian di atas, dapat disimpulkan bahwa masyarakat Islam Lhokseumawe dan Kabupaten Aceh Utara hingga kini masih mengamalkan suatu amalan-amalan yang bernuansa animisme dan dinamisme. Adat istiadat masyarakat Aceh dimaksud telah diamalkan dan dijadikan sebagai amalan dalam kehidupan sehari-hari. Amalan tersebut tidak saja dilaksanakan oleh penduduk pedesaan, tetapi juga penduduk perkotaan.

Sebelum menerima ajaran Islam, masyarakat Kota Lhokseumawe dan Kabupaten Aceh Utara telah menganut paham animisme dan dinamisme dengan memercayai berbagai kekuatan roh gaib dan makhluk halus. Lalu, kepercayaan tersebut sehingga berubah menjadi suatu paham yang dekat dengan ajaran agama Islam, meskipun bukan Islam Sunni, melainkan Syiah. Dalam hal ini, masih terdapat banyak unsur peninggalan ajaran Syiah dalam keyakinan dan ritual masyarakat setempat seperti perayaan hari Hasan Husain pada bulan Muharam. Dalam masyarakat yang tinggal dalam wilayah Kota Lhokseumawe dan Aceh Utara, terdapat berbagai jenis kue, sehingga sebagian sebutan nama kue identik dengan nama 'Ali, Fathimah, Khadijah dan Zainab.

Data-data lapangan menunjukkan bahwa baik masyarakat pedesaan maupun masyarakat perkotaan di Kota Lhokseumawe dan Aceh Utara setuju untuk mempertahankan adat dan istiadat yang berlaku dalam masyarakat, baik adat istiadat yang bertentangan maupun yang sesuai dengan ajaran Islam. Mayoritas masyarakat Islam Kota Lhokseumawe dan Aceh Utara masih melaksanakan amalan-amalan berupa acara kenduri tahlil kepada orang yang telah meninggal, karena amalan tersebut sudah sangat sulit untuk ditinggalkan dan telah diwarisi secara turun temurun.

Diketahui bahwa adat dan istiadat masyarakat yang berlaku di Kota Lhokseumawe dan Aceh Utara hingga saat ini masih banyak yang bertentangan dengan ajaran syariat Islam. Sebab, masyarakat tersebut masih tetap menerima dan melaksanakan ajaran dan kepercayaan animisme dan dinamisme. Unik bahwa mereka tidak setuju apabila dikatakan bahwa adat istiadat tersebut berasal dari budaya dan ajaran agama Hindu, dan hanya sebagian yang menyatakan bahwa adat dan budaya tersebut berasal dari ajaran agama 
Hindu. Pada umumnya, bahwa masyarakat tersebut masih cenderung berpendapat bahwa amalan tepung tawar menghasilkan keberkatan dalam hidup, tetapi sebagian penduduk perkotaan kurang meyakini pendapat tersebut.

\section{Pustaka Acuan}

Aceh, Abu Bakar. "Tentang Nama Aceh," dalam Ismail Suni (peny.), Bunga Rampai Tentang Aceh. Jakarta: Bhratara Karya Aksara, 1980.

Azmi, Wan Hussein. "Islam di Aceh: Masuk dan Berkembangnya Hingga Abad XVI," dalam A. Hasjmy (peny.) Sejarah Masuk dan Berkembangnya Islam di Indonesia. Bandung: Al-Ma'rif, 1993.

Ahmad, Kamaruzzaman Bustamam. Islam Historis: Dinamika Studi Islam di Indonesia. Yogyakarta: Galang Press, 2002.

Alamsyah, T. (peny.). Pedoman Umum Adat Aceh. Banda Aceh: Lembaga Adat dan Kebudayaan Aceh, 1991.

Bahan-bahan Seminar. Sejarah Masuk dan Berkembangnya Islam di NAD. Banda Aceh: MUI-NAD. Banda Aceh, 1978.

Barnard, Alan dan Jonathan Spencer. Enchyclopaedia of Sosial Culural Anthropology. London: Rotledge, 1996.

Braginsky. Satukan Hangat dan Dingin: Kehidupan Hamzah Fansuri, Pemikir dan Penyair Sufi Melayu. Kuala Lumpur: Dewan Bahasa dan Pustaka, 2004.

Daradjat, Zakiah (peny.). Perbandingan Agama I. Jakarta: Bumi Aksara, 1996.

Daudi, Ahmad. Syeikh Nuruddin Ar-Raniry. Jakarta: Bulan Bintang, 1978.

Departemen P dan K. Adat Istiadat Daerah Provinsi Daerah Istimewa Aceh. Banda Aceh: Departemen P dan K, 1990.

Al-ㅍanbalî, Manshûr bin Yûnus al-Bahauti. Kasyafal-Qanâ, Juz II. Kairo: Dar al-Misyriah, 1987.

Hefner, R. Hindu Javanese: Tengger Tradition and Islam. Princeton: Princeton University Press, 1984.

Ismuha. Sejarah Singkat Ulama Propinsi Daerah Istimewa Aceh. Banda Aceh: Sekretariat MUI Propinsi D.I Aceh, 1983.

Ismail, Badruzzaman. Wawancara, 22 Juli 2006.

Jessy, Joginder Singh. Malaysia Singapora dan Brunai 1400-1965. Selangor: Longman, 1975.

John, Davis. Purchas his Pilgrims, Vol. I. London: t.p., t.t.

Kasimin, Amran. Agama dan Perubahan Sosial. Kuala Lumpur: Dewan Bahasa dan Pustaka, 1991.

Kusumo, Sardono. Aceh Kembali ke Masa Depan. Jakarta: IKJ Press. 2005.

L, Daniel. Seven Theories of Religion. New York: Oxford University Press, 1996. 
MIQOT Vol. XXXVI No. 2 Juli-Desember 2012

Pasha, Musthafa Kamal, dan Ahmad Adaby Darban. Muhammmadiyah Sebagai Gerakan Islam. Yogyakarta: Pustaka SM, 1994.

Pooney, Caroline. African Literature, Aninism and Politic. London: Routledge, 2001.

Pringgodidgo, A.G. (peny.). Ensiklopedi Umum. Jakarta: Yayasan Dana Buku Franklin, 1973.

Provinsi Daerah Istimewa Aceh. Monografi Daerah Istimewa Aceh. Banda Aceh: Universitas Syiah Kuala, 1972.

Sabiq, Sayyid. Fiqh al-Sunnah, Jilid III. Beirut: al-Kitâb al-Aarabî, 1973.

Saby, Yusny. "Islam and Social Change: the of the Ulama in Acehnese Society. Disertasi Ph.D Temple University, 1995.

Subqi, Badruddin. Dilema Ulama dalam Perubahan Zaman. Jakarta: Gema Insani Press, 1995.

Al-Siba'i, Musthafa. Al-Sunnah wa Makânatubâfí Tasyri' al-Islâmi. t.t.p.: t.p, t.t.

Sufi, Rusdi (peny). Adat Istiadat Masyarakat Aceh. Banda Aceh: t.p., t.t.

Syamsuddin, T. Adat Istiadat Daerah Provinsi Daerah Istimewa Aceh. Jakarta: Departeman Pendidikan dan Kebudayaan, 1997.

Syaltût, Mahmûd. Al-Fatâwâ: Dirâsât al-Musyaqqilat al-Muslim al-Mu'sir fî Hayâtihi alYaumiyyah wa al-Mat. Kairo: Dâr al-Qalam, t.t.

Tgk. H. Mustafa Puteh, Ketua Majlis Permusyawatan Ulama (MPU) Kabupaten Aceh Utara, Wawancara, 29 Juni 2006.

Tylor, Edward B., Primitive Culture: Research into the Development of Mythology, Philosophy, Religion, Langguage, Art and Custom. New York: Brentano's Publishers, t.t.

Al-Tirmidzî, Muhammad 'Îsâ bin Surah. Sunan al-Tirmizî, Jilid II. Kuala Lumpur: Victory Agencie, t.p., 1993.

"Upacara Peusijuk," (Lhokseumawe: Lembaga Adat dan Kebudayaan Aceh (LAKA), 1988.

Al-Zahâbî, Syams al-Dîn. Al-Kabâ'ir. Beirut: Dâr al-Fikr, t.t.

Zuhailî, Wahbah. Al-Fiqh al-Islâmi wa Adillatuhu, Juz IV. Beirut: Dâr al-Fikr al-Mu'âsir, 1997. 